\title{
Complex determination of queen body size in the queen size dimorphic ant Leptothorax rugatulus (Formicidae: Hymenoptera)
}

\author{
OLAV RÜPPELL*†, JÜRGEN HEINZE + \& BERT HÖLLDOBLER† \\ $\dagger$ Zoologie II, Universität Würzburg, Biozentrum, Am Hubland, D-97074 Würzburg and $\$$ LS Biologie I, \\ Universität Regensburg, Universitätsstraße 31, D-93040 Regensburg, Germany
}

\begin{abstract}
In order to understand the evolution of natural variability, and polymorphisms in particular, it is essential to study proximate causes. Our study is the first work on ants to determine formally the heritability of quantitative traits in a quantitative genetic framework. We investigated the causes of queen size dimorphism of the ant Leptothorax rugatulus and derive from the results a possible scenario for its evolutionary maintenance. Mother size was highly predictive of daughter size in field colonies. This finding could be repeated under constant laboratory conditions. Data suggested that maternal effects via egg size are not the cause for the transmission of body size. In colonies with coexisting large and small mother queens, daughter size did not correlate with mother size, and in an additional experiment we found a negative effect of queen number on daughter size. The integration of these various results suggests a high transmissibility of body size from generation to generation. However, social (queen) influences also affect daughter size, especially in the case of mixed colonies. This complex determination fits well with an adaptive adjustment of queen size to alternative reproductive strategies.
\end{abstract}

Keywords: alternative life histories, body size, heritability, phenotypic plasticity, social insects, threshold character.

\section{Introduction}

With the recent emphasis on underlying mechanisms of adaptations and the distinction between phenotypic plasticity and genetic polymorphisms, quantitative genetics has been gaining increasing importance in evolutionary studies (Gross, 1996; Roff, 1997). Surprisingly, this approach remains mainly unexplored in studies of social insects, with the exception of the domesticated honeybee (e.g. Rothenbuhler et al., 1968; Hunt et al., 1995). Social insects provide both a special opportunity and a special challenge to disentangle environmental and genetic determinants of quantitative traits. Group living in colonies facilitates quantitative analyses, because large offspring numbers can be produced and many individuals are reared in the same environment. On the other hand, colony living and the intensive brood care add social effects (by queens, workers or brood) as

*Correspondence. E-mail: orueppell@ucdavis.edu

Present address: University of California Davis, Department of Entomology, CA 95616, USA. an additional potential influence on developing offspring (Hölldobler \& Wilson, 1990; Keller \& Ross, 1993).

While much natural variability is distributed normally around a population mean, a number of traits have two or several discrete phenotypes (Roff, 1996). These traits are particularly interesting for studying the maintenance of biological variability in evolution. Alternative phenotypes are best known from male alternative reproductive strategies, and most of these are caused by phenotypic plasticity (Eberhard \& Gutierrez, 1991; Gross, 1996). Female-specific alternative morphotypes have been documented less often (Rüppell \& Heinze, 1999). Some cases involve phenotypic plasticity (e.g. Moran, 1992) but in others a genetic basis has been suggested, mainly with one or two underlying loci (Roff, 1986; Fincke, 1994; Heinze \& Tsuji, 1995).

Apart from plasticity or single-locus determination, some genetic polymorphisms are influenced by both genes and environmental parameters, and the threshold model of quantitative genetics provides the most comprehensive theoretical concept for estimating levels of genetic determination (Roff, 1996). This model assumes an underlying, normally distributed variable that cannot 
be measured in practice. Based on the value of this variable, the organism develops into one of the alternative phenotypes. By transformation of the incidence of one phenotype in a particular group of individuals to the value of the underlying variable (liability), and assuming its normal distribution, standard quantitative genetic methods can be used to infer the heritability of the phenotypic trait (Falconer \& MacKay, 1996; Roff, 1997; Lynch \& Walsh, 1998).

Across taxa, body size constitutes one of the beststudied traits in quantitative genetics (e.g. Mousseau \& Roff, 1987) because it is commercially interesting, it has important consequences for virtually any other biological trait of organisms (Calder, 1984) and generally fulfills the assumption of a polygenic, normally distributed parameter (Falconer \& Mackay, 1996). Body size also plays an important role in the reproductive tactics of queen ants. Only queens above a certain body size can reproduce independently; relatively small queens depend on existing colonies for their reproduction (Stille, 1996). Although species differences in queen body size are well established (Stille, 1996), and it has been shown that queen weight and daughter weight correlate in several ant species (Herbers, 1990; Backus, 1993; McInnes \& Tschinkel, 1995; Herbers \& Stuart, 1996), no formal studies on the proximate causation of body size have been conducted so far. The only heritability values for body size in social insects stem from studies of the honeybee (Rothenbuhler et al., 1968; Collins et al., 1984).

The North American ant Leptothorax rugatulus, displays a large variability of queen body size, which is bimodally distributed across populations (Rüppell et al., 1998). The two morphs - macrogynes and microgynes - are specialized for independent and dependent reproduction, respectively (Rüppell et al., 2001). Most populations contain both morphs, and macro- and microgynes occasionally co-occur in colonies. Microsatellite analyses revealed no significant inbreeding within populations. A high correlation of mother and daughter size was found in field-collected colonies (Rüppell et al., 1998). This similarity could have resulted from shared genetic, environmental and social parameters. Although controlled matings are not possible, L. rugatulus constitutes a good model system to investigate the proximate causation of queen-size variability because the small colonies can be collected in sufficient numbers and kept in the laboratory under seminatural conditions (Buschinger, 1974). The genus Leptothorax provides an important study system for queen-size polymorphisms in ants (Bourke \& Franks, 1991) and studies of proximate causes are essential for our evolutionary interpretation of this phenomenon (Gross, 1996; Rüppell \& Heinze, 1999). The present study aimed at determining the importance of genetic, environmental and social factors for queen body-size by several motherdaughter regressions in laboratory experiments.

\section{Materials and methods}

Leptothorax rugatulus is a widespread ant species in the western part of the U.S.A. It occurs in mixed coniferous forests where it nests under stones and in rock crevices. Complete colonies were collected from several populations in Arizona and New Mexico during July 1996 and 1997, transferred to the laboratory, and kept under seminatural conditions in the laboratory (Buschinger, 1974).

Three laboratory fostering experiments were carried out: two experiments aimed at providing independent heritability estimates of queen size, while the third investigated the impact of the number of queens in a colony on the size of their daughters, because life history considerations and preliminary observations indicated a potential effect of this variable.

\section{Size measurements}

All size measurements were carried out with a Wild ${ }^{\mathrm{TM}}$ M3Z (Heerbrugg, Switzerland) stereomicroscope at 50× magnification. In the first experiment, maximal head width, thorax width and thorax length were measured with an ocular micrometer and averaged to a size coefficient (Rüppell et al., 1998). In the other experiments, size refers to the mean of head- and thorax-width determined to the nearest micrometre with a table mounted on a micrometer screw. Egg length and diameter were also measured on this micrometer table, and combined to approximate egg volume by (length $\times$ radius $^{2} \times \pi$ ).

\section{Experimental design}

The purpose of the first experiment was to investigate whether macrogyne and microgyne offspring would develop into their mothers' morph without the influence of the corresponding social environment. Offspring of macro- and microgynes were cross-fostered in groups of 100 workers under laboratory conditions. The worker groups were derived from native colonies by removal of all queens and brood. Unrelated macro- and microgynes were introduced for one month to lay eggs, and for two more months eggs were transferred from that queen (kept in its original colony) to the fostering colony. Microgynes were introduced into groups derived from 14 macrogynous, three mixed, and three microgynous colonies. Macrogynes were introduced into six microgynous, eight mixed, and six macrogynous worker groups. The design was unbalanced because the number of 
Table 1 Seven microsatellites were adopted from other ant species and used with different PCR-conditions. Taq ${ }^{\circledR}$ was used at $0.04 \mu \mathrm{L}^{-1}$ concentration. Initial denaturation was performed for $180 \mathrm{~s}$ at $94^{\circ} \mathrm{C}$, subsequent denaturation for $60 \mathrm{~s}$ at $92^{\circ} \mathrm{C}$, and the final elongation step for $300 \mathrm{~s}$ at $70^{\circ} \mathrm{C}$. The number of alleles for each locus gives an approximate idea about its discriminatory power for maternity assignment

\begin{tabular}{|c|c|c|c|c|}
\hline Locus & Original citation & Mastermix & Temperature profile & Number of alleles \\
\hline L4 & Foitzik et al. (1997) & $\begin{array}{l}200 \mu \mathrm{M} \mathrm{dNTPs} \\
2.5 \mathrm{~mm} \mathrm{MgCl}_{2} \\
0.63 \mu \mathrm{M} \text { Primer }\end{array}$ & $\begin{array}{l}\text { Annealing: } 56 / 51^{\circ} \mathrm{C}(60 \mathrm{~s}) \\
\text { Elongation: } 70^{\circ} \mathrm{C}(90 \mathrm{~s}) \\
\text { Cycles: } 10 / 30\end{array}$ & 5 \\
\hline L18 & Foitzik et al. (1997) & $\begin{array}{l}200 \mu \mathrm{M} \mathrm{dNTPs} \\
2.5 \mathrm{~mm} \mathrm{MgCl}_{2} \\
0.63 \mu \mathrm{M} \text { Primer }\end{array}$ & $\begin{array}{l}\text { Annealing: } 51^{\circ} \mathrm{C}(60 \mathrm{~s}) \\
\text { Elongation: } 70^{\circ} \mathrm{C}(90 \mathrm{~s}) \\
\text { Cycles: } 36\end{array}$ & 24 \\
\hline LXGT104 & Hamaguchi et al. (1993) & $\begin{array}{l}310 \mu \mathrm{M} \mathrm{dNTPs} \\
2.5 \mathrm{~mm} \mathrm{MgCl}_{2} \\
0.63 \mu \mathrm{M} \text { Primer }\end{array}$ & $\begin{array}{l}\text { Annealing: } 51^{\circ} \mathrm{C}(60 \mathrm{~s}) \\
\text { Elongation: } 70^{\circ} \mathrm{C}(90 \mathrm{~s}) \\
\text { Cycles: } 36\end{array}$ & 5 \\
\hline LXGT218 & Hamaguchi et al. (1993) & $\begin{array}{l}200 \mu \mathrm{M} \mathrm{dNTPs} \\
1.25 \mathrm{mM} \mathrm{MgCl}_{2} \\
0.56 \mu \mathrm{M} \text { Primer }\end{array}$ & $\begin{array}{l}\text { Annealing: } 57-48 / 47^{\circ} \mathrm{C}(90 \mathrm{~s}) \\
\text { Elongation: } 70^{\circ} \mathrm{C}(90 \mathrm{~s}) \\
\text { Cycles: } 10 \times 2 / 20\end{array}$ & 5 \\
\hline MYRT3 & $\begin{array}{l}\text { Evans (1993); } \\
\text { Bourke et al. (1997) }\end{array}$ & $\begin{array}{l}00 \mu \mathrm{M} \mathrm{dNTPs} \\
2.5 \mathrm{~mm} \mathrm{MgCl}_{2} \\
0.63 \mu \mathrm{M} \text { Primer }\end{array}$ & $\begin{array}{l}\text { Annealing: } 60 / 55^{\circ} \mathrm{C}(60 \mathrm{~s}) \\
\text { Elongation: } 70^{\circ} \mathrm{C}(120 \mathrm{~s}) \\
\text { Cycles: } 10 / 20\end{array}$ & 6 \\
\hline LXAGT1 & Bourke et al. (1997) & $\begin{array}{l}200 \mu \mathrm{M} \mathrm{dNTPs} \\
2.5 \mathrm{~mm} \mathrm{MgCl}_{2} \\
0.63 \mu \mathrm{M} \text { Primer }\end{array}$ & $\begin{array}{l}\text { Annealing: } 60 / 55^{\circ} \mathrm{C}(60 \mathrm{~s}) \\
\text { Elongation: } 70^{\circ} \mathrm{C}(120 \mathrm{~s}) \\
\text { Cycles: } 10 / 20\end{array}$ & 27 \\
\hline
\end{tabular}

colonies of sufficient size was restricted, and furthermore some of the initial set-ups never produced daughter queens. The sizes of mother queens and all daughters produced in the worker groups during the subsequent two years were measured (Rüppell et al., 1998). All female offspring was presumably derived from queen eggs, because production of female offspring by L. rugatulus workers (thelytoky) is unlikely: in a separate experiment, five queenless worker groups produced 130 males but no females.

The second experiment was designed to evaluate the transmission of body size under identical abiotic but different social environments. Daughter size was regressed on mother size in different kinds of colonies with several queens under laboratory conditions. At the beginning of the experiment, all larvae and eggs were removed from macrogynous, microgynous and colonies with queens of both morphs (mixed). During the peak of egg production in the first reproductive season, 10 eggs were collected from 10 macrogynous and 10 microgynous colonies and their volume compared by a nested ANOVA. Subsequently, all daughters produced during two years were collected, frozen, size measured and assigned to (size-measured) mothers by microsatellite

(C) The Genetics Society of Great Britain, Heredity, 87, 33-40. analyses. Daughters were genotyped, along with all potential mothers, at as many microsatellite loci (Table 1) as necessary for excluding for each daughter all but one mother ${ }^{1}$.

The purpose of the third experiment was to provide evidence for an influence of colony queen number on daughter size. Brood and workers of 10 polygynous, macrogynous colonies were evenly split into two segments; one queen was re-introduced in one, and the remaining queens (range $2-18$, median 4) into the other half. Any daughters produced in the following two years were collected after hatching and frozen for subsequent size measurement.

\section{Statistical analysis}

Queen-size distribution in Leptothorax rugatulus across natural populations is bimodal. As no transformation improved the fit of the data to a normal distribution, untransformed values were used. In experiment one,

\footnotetext{
${ }^{1}$ Detailed description of DNA-extraction, PCR-amplification and visualization of the products can be obtained from the first author upon request.
} 
heritability was first approximated by regressing mean offspring size on mother size. Unequal sample size between families was accounted for by weighting in proportion to the inverse of the residual sampling variance of family means about the unweighted parent-mean offspring regression (Kempthorne \& Tandon, 1953, in Lynch \& Walsh, 1998). However, both mother-size (Shapiro-Wilk's $W=0.878, n=25$, $P=0.006)$ and daughter-size distributions $(W=0.982$, $n=153, P=0.045$ ), differed significantly from normality and simple regression models were not appropriate (Falconer \& Mackay, 1996; Roff, 1996; Lynch \& Walsh, 1998).

Thus, the data were evaluated by the threshold model (Falconer \& MacKay, 1996; Roff, 1996, 1997), in addition to the regression analysis. Two independent estimates of heritability of body size were obtained, using either macrogynous or microgynous mothers. The size threshold to classify macro- and microgynes was chosen in order to maximize the congruence between the two heritability estimates. Mean liability of the parental generation was calculated as a weighted average from the incidence (the proportion of one morph) in the populations of maternal origin. Standard errors (SE) were calculated from an estimate of the sampling variance as given in Falconer \& Mackay (1996): $\sigma^{2}=(1-p) /\left(i_{\mathrm{r}}^{2} \times i_{\mathrm{p}}^{2} \times A\right)$, where $p$ is the incidence in the parental population, $i_{\mathrm{r}}$ and $i_{\mathrm{p}}$ are mean deviations of 'affected' individuals in the offspring and the parental populations from the populations' grand mean, and $A$ is the number of 'affected' offspring measured. Data from the different groups of experiment two were also evaluated in both ways using the size threshold for macroand microgyne classification from experiment one.

\section{Results}

\section{Experiment one}

In the cross-fostering experiment, an initial two-way ANOVA demonstrated that the mother class (macro- vs. microgyne) had a much stronger effect on the mean size of the cross-fostered offspring than the class of fostering colony $\left[F_{\text {colony }(2,19)}=0.62, \quad P=0.548 ; \quad F_{\text {mother }(1,19)}=\right.$ $\left.16.62, \quad P=0.001 ; \quad F_{\text {interaction }(2,19)}=3.13, \quad P=0.067\right]$. Offspring exhibited considerably lower size variance $\left(\sigma^{2}=5336\right)$ than mothers $\left(\sigma^{2}=8898\right.$; Fig. 1$)$. Macrogynous mothers produced offspring smaller than themselves, while microgynous mothers had daughters larger than themselves (Fig. 2). The regression of mean daughter size on mother size was significantly positive $[\beta=0.44 \pm 0.10(\mathrm{SE}), n=25, P<0.001$; Fig. 1$]$, which translated into a heritability estimate of $h^{2}=0.88 \pm$ 0.20 (SE). Macrogynous queens produced macrogynous



Fig. 1 Regression of the mean size of cross-fostered daughter queens of the ant Leptothorax rugatulus on the size of their original macrogynous or microgynous mothers.

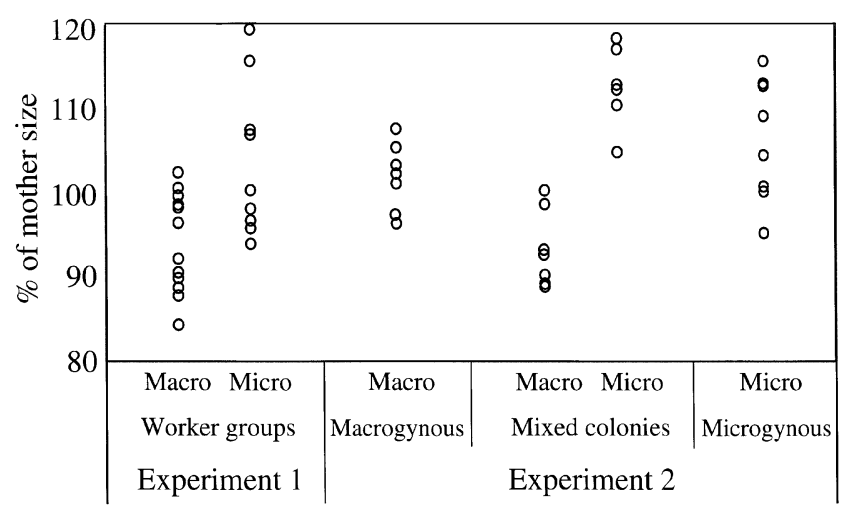

Fig. 2 Relative shifts in body size between the field-collected mothers and the laboratory daughter generation in the different experimental groups of the first two experiments. Each dot represents the mean size of daughters of one queen, relative to the size of that queen. 'Macro' and 'Micro' indicate whether offspring came from a macrogynous or microgynous queen, respectively. The second line indicates the type of colony in which that offspring was reared. Overall, the laboratory conditions increased the body size.

daughters in 58 out of 72 cases; microgynes produced 59 microgynous daughters out of 83 cases. The two heritability estimates that were obtained by the threshold approach were $h^{2}=0.62 \pm 0.19$ (macrogynes) and $h^{2}=0.82 \pm 0.05$ (microgynes). Both were not significantly different from the regression value.

\section{Experiment two}

Overall, 184 daughters of 48 mothers in 16 colonies were analysed. Queen number ranged between two and five but did not vary systematically between groups. 


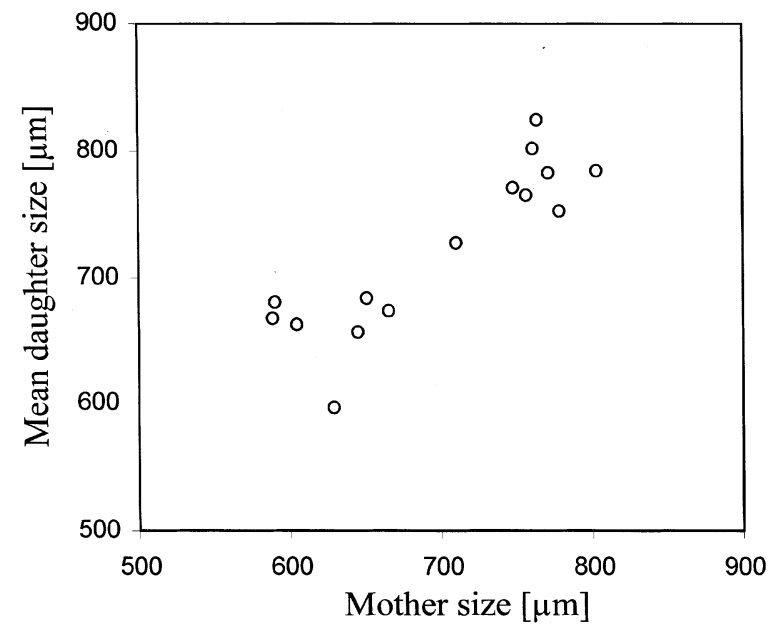

Fig. 3 Relationship between mean daughter size and mother size under constant laboratory conditions.

A two-way ANOva indicated a significant effect of colony and mother type $\left[F_{\text {colony }(2,26)}=40.29\right.$, $P<0.001 ; F_{\text {mother }(1,26)}=28.64, P<0.001$; no interaction estimate] on the mean daughter size of a queen. Overall, daughters of macrogynes [737.8 $\mu \mathrm{m} \pm$ $46.9 \mu \mathrm{m}(\mathrm{SD})]$ were larger than daughters of microgynes $(685.9 \mu \mathrm{m} \pm 37.0)$. Daughters in macrogynous colonies were larger $(776.2 \mu \mathrm{m} \pm 28.0)$ than daughters in mixed (705.6 $\mu \mathrm{m} \pm 23.6)$ and microgynous colonies (659.9 $\mu \mathrm{m} \pm 29.2)$.

In the combined sample of macro- and microgynous colonies, the regression of mean daughter size on mother size was significantly positive and the regression coefficient higher than in experiment one $(\beta=0.88 \pm 0.12$, $n=16, P<0.028$; Fig. 3). Accordingly, a determination of the 'heritability' (measured as a combination of $h^{2}$ and potential maternal effects) by the threshold approach yielded for macrogynes $h^{2}=3.68 \pm 0.60$ (40 out of 43 daughters were macrogynous), and for microgynes $h^{2}=1.45 \pm 0.20$ (28 out of 35 daughters were microgynous). This suggests that the transmission of size from mothers to daughters was increased by social (maternal) influences. Maternal effects via egg mass were not important because egg volume of macrogynes $\left(3.301 \times 10^{-2} \mathrm{~mm}^{3} \pm 0.5698 \times 10^{-2} \mathrm{~mm}^{3}\right)$ and microgynes $\left(3.3789 \times 10^{-2} \mathrm{~mm}^{3} \pm 0.4609 \times 10^{-2}\right)$ did not differ $\left(F_{1,180}=1.96, P=0.163\right)$. Laboratory rearing resulted in both groups in an average increase in body size between mother and daughter generation (Fig. 2).

In order to determine within-morph heritability of body size, mother-daughter regressions were carried out separately in the samples of macrogynous and microgynous colonies. In our small sample, both regression coefficients were statistically indistinguishable from



Fig. 4 Relationship between mean daughter size and mother size in colonies with coexisting macro- and microgynous queens; no correlation between mother size and daughter size existed.

zero (macrogynes: $\beta=0.05 \pm 0.43, n=5, \quad P=0.915$; microgynes: $\beta=0.49 \pm 0.33, n=7, P<0.177$ ).

In mixed colonies, the regression of mean daughter size on mother size was nonsignificant $(\beta=-0.29 \pm$ $0.28, n=14, P=0.308$; Fig. 4). Daughters produced by microgynes and macrogynes did not differ in size $\left[t_{(14)}=-0.99, P=0.342\right]$. According to the threshold determined in experiment one, macrogynes produced new macrogynes in 41 out of 57 cases, leading to a heritability estimate of $h^{2}=1.82 \pm 0.03$. Microgynous queens produced new microgynes in only 13 out of 49 cases, leading formally to a heritability estimate of $h^{2}=-5.34 \pm 0.18$. The tendency for macrogynes to produce smaller and microgynes larger daughters than themselves was stronger than in the first experiment (Fig. 2).

\section{Experiment three}

A pair-wise analysis of the split colonies to test for an effect of queen number was precluded by the low overall queen production. In only two cases did both colony halves produce daughters. Overall however, monogynous colony halves produced larger daughters [\% of mother size: $x=99.6 \pm 3.9(\mathrm{SD})]$ than polygynous colony halves $\left[x=90.3 \pm 7.2 ; \quad F_{(1,82)}=79.45\right.$, $P<0.0001]$.

\section{Discussion}

To our knowledge, this study is the first to use the formal power of quantitative genetics to determine the heritability of a trait in ants, which are otherwise an 
important taxon for ecological and evolutionary studies (Hölldobler \& Wilson, 1990). Thus far, studies have demonstrated a genetic influence on certain traits without quantifying the influence (Stuart \& Page, 1991; Fraser et al., 2000) and some further studies have shown inheritance patterns that accord with a singlelocus trait, despite environmental influence (Winter \& Buschinger, 1986; Heinze \& Buschinger, 1989). Our approach of regressing the phenotypes of lab-reared progeny on the phenotypes of their field-collected parents provides a minimum estimate of $h^{2}$ (Riska et al., 1989; see also Coyne \& Beecham, 1987).

The linear regression model and the threshold model for queen body-size in Leptothorax rugatulus generated similar results in our experiments. This suggests that queen body-size in queen-size dimorphic ants can correctly be regarded as a complex binary trait, as has already been suggested by Roff (1996). However, our studies also reveal that the threshold model is problematic because two additional parameters have to be estimated for parent-offspring comparison. These are the incidence of the trait in the parental population(s), and in continuous traits, such as body size, the exact threshold size to assign queens to either trait class. Conversely, the more simple regression model probably overestimates the heritability owing to the bimodality of the parental generation. Furthermore, a slight overestimation of the heritability by both models is expected because a weak population subdivision was found (Rüppell et al., 2001), which leads to assortative mating.

Generally, each experimental estimate of heritability is context dependent (Mitchell-Olds \& Rutledge, 1986; Falconer \& Mackay, 1996; Roff, 1997) and independent estimates seldom agree (Mousseau \& Roff, 1987). This difficulty is augmented in social insects in which even under constant laboratory conditions social influences cannot be excluded. While it is difficult to study or exclude some of these influences (e.g. queen- and colony age), we deliberately chose to explore the heritability of queen size under different social conditions. The results differed strongly from each other and thus we cannot conclude a simple rule for body size determination in L. rugatulus. Instead, conditional rules apply (based on colony state) which translate into an evolutionary scenario explaining the dynamics and maintenance of macrogyny and microgyny in at the meta-population level.

In the heterogeneous habitat of Leptothorax rugatulus, new populations are probably founded exclusively by macrogynes because microgynes readopt into their natal colony as part of their reproductive strategy (Rüppell et al., 2001). In these macrogynous colonies, transmission of body size is high (experiment two), independent of the colony environment (e.g. temperature, moisture, food, etc.). The resulting macrogynous daughters found new colonies independently (with a few dispersing to new areas), until the local habitat becomes saturated. The resulting nest site limitation causes macrogynes to readopt into their mother colonies which leads to an increase in colony queen number (Herbers, 1993; Rüppell et al., 2001). This increase in queens in the colonies causes the daughter size to decrease as a result of social effects (experiment three). This effect may be adaptive because daughters who return to their natal colony do not require large body reserves for independent founding (Stille, 1996). Heritability of body size in this transition phase (with many mixed colonies) is low, as shown in the mixed colonies of experiment two. Eventually, colonies will be purely microgynous (apart from immigrants) and only produce microgynes regardless of their environment (experiment two). In this context, it would be interesting to evaluate whether environmental deterioration could cause a shift back to production of the dispersal form (macrogynes) but currently there is no evidence for this. In the case of queen loss, colonies simply produce daughters similar to their mothers (experiment one).

Integration of results in this study allows for some conclusions about proximate causation of queen size. Our results suggest that colony-external parameters cannot be responsible for the high correlation between queen mother and daughter size in natural colonies (Rüppell et al., 1998). When the social influence of the queen mother is removed, eggs still display an innate tendency to develop into their mothers' queen morph. This autonomous developmental bias of eggs may be the result of genes transmitted by the mother or maternal effects (Bernardo, 1996a). Egg size, which is of prevalent importance for maternal effects (Bernardo, 1996b), seems not to be responsible because macrogynous colonies produced significantly larger daughters than microgynous colonies in experiment two, with no difference in egg size. Nevertheless, maternal effects based on egg composition, such as RNAs or proteins, cannot be excluded. The previous interpretation of a high mother-daughter size correlation in several ant species as evidence for genetic determination (Elmes, 1991; McInnes \& Tschinkel, 1995) is clearly too simplistic in the light of the results presented herein.

As shown in the mixed colonies of experiment two, the transmissibility of body size can be entirely superseded by social (queen) influences. In ants various ways of brood manipulation are conceivable. It has been reported from several species that mature queens have a negative effect on the number of new queens that develop in a colony (Brian, 1983; Elmes, 1991; Bourke \& Franks, 1995). It is also possible that this queen effect influences the size of new queens produced, as was 
shown in Leptothorax longispinosus (Herbers, 1990; Backus, 1993). Either the queen effect occurs directly via pheromones (e.g. Vargo \& Fletcher, 1986; Vargo \& Passera, 1991) or by manipulation of the workers' brood care behaviour (Brian, 1973; Elmes \& Wardlaw, 1983). Furthermore, workers are expected to influence larvae according to their own fitness interests. Workers should inhibit sexual female development when there is kin conflict over caste determination and this may result in smaller queens (Bourke \& Ratnieks, 1999).

In conclusion, the queen-size dimorphism in L. rugatulus has a strong transmissible component inherent in the egg. In contrast to this, body size within each morph is not related between mother and daughter. The transmission of macro- and microgyny can be superseded by social queen influences: queen number decreases daughter size, and in mixed colonies no mother-daughter correlation exists. This plasticity probably plays an adaptive role in the adjustment of body size to the ecologically favoured reproductive mode (Björklund, 1996).

\section{Acknowledgements}

We are grateful to the South-western Research Station of the American Museum of Natural History for essential infrastructure and excellent help during the field work. We would also like to thank D. Roff and T.R. Famula for valuable theoretical advice, two anonymous referees for their comments and M.C. Kalcounis-Rüppell for proofreading the manuscript. Financial support came from the German Scholarship Foundation, the German Science Foundation (SFB 554), the TMRprogram 'Social Evolution' of the EU, and the AMNH.

\section{References}

BACKUS, V. L. 1993. Packaging of offspring by nests of the ant Leptothorax longispinosus: parent-offspring conflict and queen-worker conflict. Oecologia, 95, 283-289.

Bernardo, J. 1996a. Maternal effects in animal ecology. Am. Zool., 36, 83-105.

BERNARDO, J. 1996b. The particular effect of propagule size, especially egg size: Patterns, models, quality of evidence and interpretations. Am. Zool., 36, 216-236.

BJÖRKLUND, M. 1996. The importance of evolutionary constraints in ecological time scales. Evol. Ecol., 10, 423-431.

BOURKE, A. F. G. AND FRANKS, N. R. 1991. Alternative adaptions, sympatric speciation and the evolution of parasitic, inquiline ants. Biol. J. Linn. Soc., 43, 157-178.

BOURKe, A. F. G. AND FRANKS, N. R. 1995. Social Evolution in Ants. Princeton University Press, Princeton, NJ.

BOURKe, A. F. G. AND RATNIEKS, F. L. W. 1999. Kin conflict over caste determination in social Hymenoptera. Behav. Ecol. Sociobiol., 46, 287-297.
BOURKE, A. F. G., GREEN, H. A. A. AND BRUFORD, M. W. 1997. Parentage, reproductive skew and queen turnover in a multiple-queen ant analysed with microsatellites. Proc. $R$. Soc. B, 264, 277-283.

BRIAN, M. V. 1973. Caste control through worker attack in the ant Myrmica. Insect Soc., 20, 87-102.

BRIAN, M. V. 1983. Social Insects. Chapman \& Hall, London.

BUSCHINGER, A. 1974. Experimente und Beobachtungen zur Gründung und Entwicklung neuer Sozietäten der sklavenhaltenden Ameisen Harpagoxenus sublaevis (Nyl.). Insect Soc., 21, 381-406.

CALDER, w. A. I. 1984. Size, Function and Life History. Harvard University Press, Cambridge, MA.

COLLINS, A. M., RINDERER, T. E., HARBO, J. R. AND BROWN, M. A. 1984. Heritabilities and correlations for several characters in the honey bee. J. Hered., 75, 135-140.

COYNE, J. A. AND BEECHAM, E. 1987. Heritability of two morphological characters within and among natural populations of Drosophila melanogaster. Genetics, 117, 727-737.

EBERHARD, w. G. AND GUTIERREZ, E. E. 1991. Male dimorphisms in beetles and earwigs and the question of developmental constraints. Evolution, 45, 18-28.

ELMES, G. W. 1991. The social biology of Myrmica ants. Actes Coll. Insectes Soc., 7, 17-34.

ELMES, G. W. AND WARDLAW, J. C. 1983. A comparison of the effect of a queen upon the development of large hibernated larvae of six species of the genus Myrmica (Hym. Formicidae). Insect Soc., 30, 134-148.

EVANS, J. D. 1993. Parentage analyses in ant colonies using simple sequence repeat loci. Mol. Ecol., 2, 393-397.

FALCONER, D. S. AND MACKAY, T. F. C. 1996. Quantitative Genetics, 4th edn. Longman, Harlow.

FINCKE, O. M. 1994. Female colour polymorphism in damselflies: failure to reject the null hypothesis. Anim. Behav., 47, 1249-1266.

FOITZIK, S., HABERL, M., GADAU, J. AND HEINZE, J. 1997. Mating frequency of Leptothorax nylanderi ant queens determined by microsatellite analysis. Insect Soc., 44, 219-228.

FRASER, V. S. B., KAUFMANN, B., OLDROYD, B. P. AND CROZIER, R. H. 2000. Genetic influence on caste in the ant Camponotus consobrinus. Behav. Ecol. Sociobiol., 47, 188-194.

GROss, M. R. 1996. Alternative reproductive strategies and tactics: diversity within sexes. Trends Ecol. Evol., 11, 92-98.

HAMAGUCHI, K., ITÔ, Y. AND TAKENAKA, O. 1993. GT Dinucleotide repeat polymorphisms in a polygynous ant, Leptothorax spinosior and their use for measurement of relatedness. Naturwissenschaften, 80, 179-181.

HEINZE, J. AND BUSCHINGER, A. 1989. Queen polymorphism in Leptothorax spec. A: its genetic and ecological background (Hymenoptera: Formicidae). Insect Soc., 36, 139-155.

HEINZE, J. AND TSUJI, K. 1995. Ant reproductive strategies. Res. Popul. Ecol., 37, 135-149.

HERBERS, J. M. 1990. Reproduction investment and allocation ratios for the ant Leptothorax longispinosus: sorting out the variation. Am. Nat., 136, 178-208.

HERBERS, J. M. 1993. Ecological determinants of queen number in ants. In: Keller, L. (ed.) Queen Number and Sociality in Insects, pp. 262-293. Oxford University Press, Oxford. 
Herbers, J. M. AND StUART, R. J. 1996. Patterns of reproduction in southern versus northern populations of Leptothorax ants (Hymenoptera: Formicidae). Ann. Entomol. Soc. Am., 89, 354-360.

HÖlldobleR, B. AND Wilson, E. O. 1990. The Ants. The Belknap Press of Harvard University Press, Cambridge, MA.

HUNT, G. J., PAGE, R. E., FONDRK, M. K. AND DULlUM, C. J. 1995. Major quantitative trait loci affecting honey bee foraging behavior. Genetics, 141, 1537-1545.

Keller, L. AND ROSS, K. G. 1993. Phenotypic plasticity and 'cultural transmission' of alternative social organizations in the fire ant Solenopsis invicta. Behav. Ecol. Sociobiol., 33, 121-129.

LYNCH, M. AND WALSh, B. 1998. Genetics and Analysis of Quantitative Traits. Sinauer Associates, Sunderland, MA.

McINNES, D. A. AND TSCHINKEL, w. R. 1995. Queen dimorphism and reproduictive strategies in the fire ant Solenopsis geminata (Hymenoptera: Formicidae). Behav. Ecol. Sociobiol., 36, 367-375.

MITCHELL-OLDS, T. AND RUTLEDGE, J. J. 1986. Quantitative genetics in natural plant populations: a review of the theory. Am. Nat., 127, 379-402.

MORAn, N. A. 1992. The evolution of aphid life cycles. Ann. Rev. Entomol., 37, 321-348.

MOUSSEAU, T. A. AND ROFF, D. A. 1987. Natural selection and the heritability of fitness components. Heredity, 59, 181-197.

RISKA, B., PROUT, T. AND TURELLI, M. 1989. Laboratory estimates of heritabilities and genetic correlations in nature. Genetics, 123, 865-871.

ROFF, D. A. 1986. The evolution of wing polymorphism in insects. Evolution, 40, 1009-1020.

ROFF, D. A. 1996. The evolution of threshold traits in animals. Q. Rev. Biol., 71, 3-35.
ROFF, D. A. 1997. Evolutionary Quantitative Genetics. Chapman \& Hall, New York, 493 pp.

ROTHENBUHLER, W. C., KULINÈEVIÆ, J. M. AND KERR, W. E. 1968. Bee genetics. Ann. Rev. Genet., 2, 413-438.

RÜPPELL, O. AND HEINZE, J. 1999. Alternative reproductive tactics in females: the case of size polymorphism in winged ant queens. Insect Soc., 46, 6-17.

RÜPPELL, O., HEINZE, J. AND HÖLLDOBLER, B. 1998. Size dimorphism in the queens of the North American ant Leptothorax rugatulus. Insect Soc., 45, 67-77.

RÜPPELL, O., HEINZE, J. AND HÖLLDOBLER, B. 2001. Alternative reproductive tactics in the queen size dimorphic ant Leptothorax rugatulus (Emery) and population genetic consequences. Behav. Ecol. Sociobiol., 50, 189-197.

STILLE, M. 1996. Queen/worker thorax Volume ratios and nestfounding strategies in ants. Oecologia, 105, 87-93.

STUART, R. J. AND PAGE, R. E. 1991. Genetic component to division of labor among workers of a leptothoracine ant. Naturwissenschaften, 78, 375-377.

VARGO, E. L. AND FLETCHER, D. J. C. 1986. Evidence of pheromonal queen control over the production of male and female sexuals in the fire ant, Solenopsis invicta. J. Comp. Physiol. A, 159, 741-749.

VARGo, E. L. AND PASSERA, L. 1991. Pheromonal and behavioral queen control over the production of gynes in the Argentine ant Iridomyrmex humilis (Mayr). Behav. Ecol. Sociobiol., 28, 161-169.

WINTER, U. AND BUSCHINGER, A. 1986. Genetically mediated queen polymorphism and caste determination in the slavemaking ant Harpagoxenus sublaevis (Hymenoptera: Formicidae). Entomol. Gen., 11, 125-137. 